\author{
(c) A. Jan' , H. $\operatorname{Jan}^{2}$, Z. Ullah'
}

${ }^{1}$ Кафедра фармации, университет Пешавара, Пешавар, Пакистан

${ }^{2}$ Кафедра химии, Исламия-колледж, Пешавар, Пакистан

Влияние генетических факторов на развитие сахарного диабета 2 типа (СД2) крайне многогранно и до сих пор остается одним из главных вопросов диабетологии. В 2006 г. важным шагом в поиске генетических факторов развития СД2 стала идентификация гена TCF7L2, который является важным маркером предрасположенности к СД2 почти у всех этнических групп. Недавние генетические исследования выявили множество новых генов, ассоциированных с повышенным риском развития СД2. Среди этих генов TCF7L2 оказался наиболее многообещающим, связанным с СД2. Генотипы TCF7L2 оказывают влияние на развитие бета-клеток поджелудочной железы и секрецию инсулина, воздействуя на сигнальный путь Wnt. Определенные полиморфизмы гена TCF7L2 увеличивают риск развития СД2, изменяя экспрессию фактора транскрипции (который играет ключевую роль в регуляции уровня глюкозы в крови) в поджелудочной железе. Цель данной статьи - представить всесторонний обзор исследований по ассоциации полиморфизма TCF7L2 с CД2, проведенных в различных этнических группах во всем мире.

КЛЮЧЕВЫЕ СЛОВА: фактор транскрипчии-7 (TCF7L2); сахарный диабет 2 типа; сигнальный путь Wnt; полногеномный поиск ассочиачий (GWAS)

\title{
TRANSCRIPTION FACTOR 7-LIKE 2 (TCF7L2): A CULPRIT GENE IN TYPE 2 DIABETES MELLITUS
}

\author{
(c) Asif Jan', Humerah Jan², Zaki Ullah
}

'Department of Pharmacy, University of Peshawar, Pakistan

${ }^{2}$ Department of Chemistry, Islamia College University, Peshawar, Pakistan

The genetics of Type 2 diabetes a complex metabolic disorder, characterized by decreased insulin secretion and insulin resistance resulting in impaired blood glucose homeostasis remains enigma for geneticists. In 2006 an important step while finding genetic causes of diabetes type 2 was identification of transcription factor 7-like 2 (TCF7L2) gene an important marker in predisposition of type 2 diabetes in almost all ethnic population. Recent genetic research identifies numerous novel type 2 diabetes susceptible genes among these genes TCF7L2 is considered as gang head and emerged as the most promising types 2 diabetes causing gene. Risk variants in TCF7L2 effects pancreatic beta cell development and insulin secretion by influencing Wnt Signaling pathway. Genetic variants in TCF7L2 confer risk for type 2 diabetes by altering expression of transcription factor (which has key role in blood glucose regulation) in pancreas. The purpose of this paper is to evaluate type 2 diabetes susceptible gene the TCF7L2 and to present a comprehensive review of studies carried out worldwide in different ethnic population on association of TCF7L2 polymorphism with type 2 diabetes.

KEYWORDS: Transcription factor-7- like 2(TCF7L2); Type 2 diabetes; Wnt signaling pathways; Genome wise association studies (GWAS)

Non communicable diseases (NCDs) are rising as the main cause of death, disability, reduced quality of life and rising health care costs worldwide. The number of people dying worldwide due to Non communicable diseases (NCDs) is twice than that of the combined infectious diseases (like HIV/AIDS, tuberculosis and malaria), maternal and prenatal conditions and nutritional deficiencies [1]. Cardiovascular diseases (CVD) cancers and chronic respiratory diseases, diabetes mellitus (DM) are the commonly NCDs, diabetes a commonly occurring NCD ranked fourth among these NCDs. Diabetes mellitus occurred in low and middle income countries especially in south Asians[2,3]. Diabetes Mellitus (DM) is a metabolic syndrome (with increased blood glucose level as a hallmark) arising from endocrine disorder that affect around $6 \%$ of the world's population $[4,5]$. Diabetes is accompanied by micro- and macro-vascular complica- tions [6]. Diabetes causing 1.5 million global deaths each year. It has two main types namely Type 1 DM (T1D) and Type 2 DM (T2D), the latter being $90-95 \%$ of total cases globally $[7,8]$. Poor lipid profile, lack of exercise, improper diet habits, socio-economic problems, central adiposity, inadequate health systems and environmental factors contributes to the development of T2D. Though lifestyle and environmental factors contribute to the development of DM but it does not completely explain its increased prevalence, and genetic has a significant role in its occurrence [9].

\section{TYPE 2 DIABETES GENETIC ARCHITECTURE AND EARLY GENETICS}

Inheritance no doubt has a key role in predisposition of diabetes type 2 [10].Geneticist argued that genomics of T2D is 
explored well to understand and manage the pathogenesis of T2D [11]. These claims are premature according to others [12]; in fact, a few have doubt in contribution of genetic predisposition to T2D pathogenesis [13]. In Sixteenth century Peter Frank a physician from Montpellier for the every first time suggest that heredity is playing a role in diabetes [14]. The Frank's view was supported by subsequent finding in 1950s and it was concluded that family history and genetics heterogeneity has a principal role in the predisposition of diabetes [15]. Earlier studies were mostly carried out on specific genes (i.e. those involved in glucose homeostasis) [16]. Considerable research by the end of 2005 was carried out throughout the world in spite of vast research only two genes polymorphism were found to be associated with type 2 diabetes: were E23K in KCNJ11 and P12A in PPARG $[17,18]$. Mutation in these genes causes monogenic diabetes $[19,20]$. In recent years genetics of diabetes type 2 is well explored due to advancement in molecular biology and also thanks to genome wide association study (GWAS) which facilitates the researcher in identifying various loci that is associated the diabetes [21,22]. Number of risk loci associated with diabetes type 2 is climbed up from just 3 identified in 2006 to more approximately 70 today, nevertheless up-to-date 90 genetic loci involved in the pathogenesis of T2D is identified by GWAS [23,24].

\section{TCF7L2; A GUILTY GENE IN TYPE 2 DIABETES}

DECODE group of Iceland in the start of 2006 revealed the transcription factor-7- like 2 (TCF7L2) as an unexpected suspect gene for a diabetes type 2 [25]. After 2006 this gene drawn attention of geneticists and soon it was confirm that multiple polymorphisms in this gene has strong association with diabetes type 2 in multiple ethnic population. After the initial signals from DECODE group in Iceland widespread study is carried in white Europeans [26], Indians and Japanese [27-29], Mexican Americans [30], Chinese [31], and West Africans [32]. Studies in all racial population shows strong association of transcription factor-7- like 2 (TCF7L2) with diabetes type 2 . Tracking of guilty genes nowadays is quite easy using new technologies. Due to technological advances, genetic variants in genes found guilty in diabetes can be assessed on a single chip. Recent advancement in genetic studies and genome wide association study has completely un-mask the complete genetic makeup of diabetes type 2 and identified number of variants in TCF7L2 associated with diabetes type 2 , among other guilty genes it is the most promising gene in the development if type 2 diabetes [33-37].

\section{EXPLORING BIOCHEMISTRY OF TCF7L2}

TCF7L2 gene (Alternate names (1) T-cell-specific transcription factor 4, (2) HMG box transcription factor 4) encodes a protein, the Transcription factor 7-like 2 (T-cell specific) containing a transcription factor which has key role in blood glucose regulation in humans [38]. Cytogenetic location of this polymorphic gene is 10q25.2-q25.3 [39]. It contains 18 exons, 619 amino acids and exists in helix-turn-helix structure [40].Transcription factor 7-like 2 belongs to a family of transcription factors known as TCF/LEF family (containing TCF7 (TCF-1),TCF7L1 (TCF-3),TCF7L2 (TCF-4) and LEF1) these transcription factors binds to DNA via SOX-like high mobility group domain [41]. TCF/LEF family member specifically TCF7L2 regulate WNT pathway which has critical role in embryonic development of pancreas and islets, cell proliferation, Causation of several cancers, Regulation of adiposeness, and release of glucagon-like peptide-1 (GLP-1) from intestinal endocrine L-cells which effect two things mainly first it effect insulin secretion secondly the generation of new $\beta$ stem cells from the ductal precursor cells and hence has critical role in controlling glucose homeostasis $[42,43]$. The TCF7L2 is distributed and expressed in brain, pancreas, liver, intestine and fat cells [44].

\section{JOURNEY OF TCF7L2 ASSOCIATED STUDIES FROM 2006 (EARLIER GENETIC STUDIES) TO 2020 (RECENT GENETIC STUDIES)}

Grant et.al and saxena et.al in 2006 for the first time correlate polymorphism in TCF7L2 with type 2 diabetes. Before that Pub-Med software was search for keyword TCF7L2 reveals 218 articles but none of that shared the term "diabetes" means the grant et al (2006) and saxena et.al (2006) are the pioneer in correlating TCF7L2 polymorphism with incidence of diabetes type 2. After that TCF7L2 replication studies were carried out word wide in different ethnic population each study conforming strong association of TCF7L2 with type 2 diabetes [45]. A comprehensive list of studies on Type 2 Diabetes Susceptibility Gene TCF7L2 rite from 2006, year of its discovery to 2019 is enlisted in the table 1.

\section{TCF7L2 A CANDIDATE GENE FOR TYPE 2 DIABETES, CONFORMATION VIA GENOME WIDE ASSOCIATION STUDY:}

Genome-wide association studies are well-powered, systemic, organized and comprehensive survey to explore and identify the link of various genetic variation (SNPs) and disease predisposition on large genomic scale [46]. Genome wide association studies as laid down spectacular advances in finding genetic cause of the diseases like cancer, diabetes, kidney failure, depression, asthma and many more. Promising Genome wide association studies also found TCF7L2 gene culprit in diabetes Type 2 [47]. In earlier genetic study era (start of 2007), two stage genome wide associations was conducted to identify different risk loci in TCF7L2. At stage first a meta analysis was conducted in 2367 French patients a consent form was signed from all patients and studied was approved by ethics committee of French general health hospital and Imperial College London, the study results show strong association of TCF7L2 with diabetes type 2 [48]. Second stage (late in year 2007) a huge genomic study was conducted in UK white population. In this study geneticist included a new parameter of association of TCF7L2 with diabetes type 1 as some geneticist in that time predict that type 1 diabetes is nothing but severe case of type 2 diabetes. All identified SNPs of TCF7L2 in this study shows strong association with type 2 diabetes but no association with type 1 diabetes confirming type 1diabetes as an autoimmune disease [49]. Later further genome wide association studies carried out in different ethnic population stamped TCF7L2 as a guilty gene in type 2 diabetes $[50,51]$. 
Table 1. List of studies on Type 2 Diabetes associated Gene TCF7L2 from 2006-2020

\begin{tabular}{|c|c|c|c|c|}
\hline S.No & $\begin{array}{c}\text { Selected } \\
\text { population }\end{array}$ & Design & Aim of study and SNPs Explored & $\begin{array}{c}\text { Reference } \\
\text { and year } \\
\text { of publication }\end{array}$ \\
\hline
\end{tabular}

\begin{tabular}{|c|c|c|}
\hline 1 & $\begin{array}{l}\text { American } \\
\text { population }\end{array}$ & Association study \\
\hline 2 & $\begin{array}{l}\text { Italic } \\
\text { population }\end{array}$ & Association study \\
\hline 3 & Scotland U.K & $\begin{array}{l}\text { Association study. } \\
\text { Case-control design. }\end{array}$ \\
\hline 4 & $\begin{array}{l}\text { Finnish } \\
\text { population }\end{array}$ & Association study \\
\hline 5 & $\begin{array}{l}\text { European } \\
\text { Population }\end{array}$ & Association study \\
\hline 6 & North India & Association study \\
\hline 7 & $\begin{array}{l}\text { Multiple ethnic } \\
\text { group }\end{array}$ & Meta Analysis \\
\hline 8 & $\begin{array}{l}\text { East Asian } \\
\text { population }\end{array}$ & Meta-analysis \\
\hline 9 & $\begin{array}{l}\text { Iranian } \\
\text { population }\end{array}$ & Association study \\
\hline 10 & $\begin{array}{l}\text { German } \\
\text { population }\end{array}$ & Case control study \\
\hline 11 & $\begin{array}{l}\text { Polish } \\
\text { population }\end{array}$ & Case control study \\
\hline 12 & $\begin{array}{l}\text { Austria } \\
\text { population }\end{array}$ & Association study \\
\hline 13 & $\begin{array}{l}\text { Multi ethnic } \\
\text { population }\end{array}$ & Meta analysis \\
\hline 14 & $\begin{array}{l}\text { Northern } \\
\text { Chinese } \\
\text { population }\end{array}$ & Case control study \\
\hline 15 & $\begin{array}{l}\text { Southern } \\
\text { Chinese } \\
\text { population }\end{array}$ & Case control study \\
\hline 16 & $\begin{array}{l}\text { Chinese Han } \\
\text { population }\end{array}$ & Meta analysis \\
\hline
\end{tabular}

SNP rs12255372 in the TCF7L2 gene was associated

Munoz et al.

with betacell function.

(2006)

TCF7L2 variant rs7903146 shows significant Melzer et al.

association with diabetes type 2

(2006)

rs790314 variant of TCF7L2 shows strong association Kimber et al.

with diabetes type 2 .

(2007)

A TCF7L2 SNP rs12255372, is strongly associated Scot et al.

with diabetes type 2

(2007)

The presence of the TCF7L2 rs7903146 risk allele Stéphane et al.

increases risk for diabetes.

(2008)

Four TCF7L2 SNPs (rs7903146, rs11196205, Sanghera et al.

rs10885409) associated with T2D

(2008)

TCF7L2 four SNPs in various ethnicities, containing rs7903146 rs7901695, rs12255372 and rs11196205

Tong et al.

is linked with diabetes type 2

(2009)

rs7903146 T, rs12255372 T, rs11196205 and rs290487 Luo et al.

of TCF7L2 confer risk of type 2 diabetes.

(2009)

In Iranian population TCF7L2 variant rs7903146 is Amoli et al.

associated with type 2 diabetes

(2010)

The following SNPs rs7903146, rs12255372, rs11196205, Haupt et al. and rs7895340 in TCF7L2 confer risk for T2D

(2010)

Risk variant rs7903146 in the TCF7L2 gene show

increase risk for diabetes type 2

Buraczynska et al.

TCF7L2 variants rs7903146 rs12255372, and

rs11196205 are associated with coronary artery disease specifically in patients with T2DM

(2011)

TCF7L2 SNPs rs7903146, rs12255372, rs7895340

and rs4506565 confer risk of type 2 diabetes

Muendlein et al.

(2011)

Northern Chinese population having rs290487

in TCF7L2 is associated with type 2 diabetes

Peng et al.

(2012)

The rs7903146 SNP of the TCF7L2 gene increases

susceptibility to T2DM in Chinese population

Qiao et al.

(2012)

This study concluded rs7903146C/T polymorphism

of the TCF7L2 gene is associated in Chinese Han

population

Wang et al.

(2012)

The TCF7L2 SNP rs7903146 (C/T)

$17 \begin{aligned} & \text { Southern-Brazil Case control study } \\ & \text { population }\end{aligned}$

Confer risk of type 2 diabetes mellitus in Southern-

Brazil

Dou et al.

(2013)

rs7903146 variant of TCF7L2 is found guilty in Indian

populations.

Assmann et al.

(2013)

$\begin{array}{lll}18 & \begin{array}{l}\text { Indian } \\ \text { populations. }\end{array} & \text { Case control study } \\ 19 & \begin{array}{l}\text { Iranian Kurdish } \\ \text { Ethnic Group }\end{array} & \text { Case control study } \\ \end{array}$

rs7903146, rs12255372, and rs290487 SNPs of TCF7L2 are associated with T2DM

Hussain et al.

(2014)

rs12255372, rs7901695 variants in TCF7L2

is associated with diabetes type 2 .

Shokouhi et al.

(2014)

Yao et al.

(2015)

TCF7L2 varaint rs12255372 (G>T) polymorphism

Yang et al. is genetic factors associated with Type 2 diabetes.

(2015) 


\begin{tabular}{|c|c|c|c|c|}
\hline S.No & $\begin{array}{l}\text { Selected } \\
\text { population }\end{array}$ & Design & Aim of study and SNPs Explored & $\begin{array}{c}\text { Reference } \\
\text { and year } \\
\text { of publication }\end{array}$ \\
\hline 20 & $\begin{array}{l}\text { Tianjin } \\
\text { Population } \\
\text { China }\end{array}$ & Meta analysis & $\begin{array}{l}\text { Transcription factor 7-like } 2 \text { (TCF7L2) SNP rs7903146 } \\
\text { is associated with T2D }\end{array}$ & $\begin{array}{l}\text { Guan et al. } \\
(2016)\end{array}$ \\
\hline 22 & $\begin{array}{l}\text { Venezuela } \\
\text { population }\end{array}$ & $\begin{array}{l}\text { Pilot case control } \\
\text { study }\end{array}$ & $\begin{array}{l}\text { We find strong association of the rs7903146 SNP } \\
\text { of TCF7L2 with T2DM }\end{array}$ & $\begin{array}{l}\text { Moran et al. } \\
(2016)\end{array}$ \\
\hline 23 & $\begin{array}{l}\text { Caucasians } \\
\text { population }\end{array}$ & $\begin{array}{l}\text { Multi ethnic Cohort } \\
\text { study }\end{array}$ & $\begin{array}{l}\text { TCF7L2 rs7903146 risk allele was associated with } \\
\text { diabetes type } 2 \text { in Caucasians }\end{array}$ & $\begin{array}{l}\text { Cropano et al. } \\
(2017)\end{array}$ \\
\hline 24 & $\begin{array}{l}\text { Turkish } \\
\text { population }\end{array}$ & Case control study & $\begin{array}{l}\text { TCF7L2 variants rs7903146, rs12255372 is found } \\
\text { culprit in T2D }\end{array}$ & $\begin{array}{l}\text { Kaya et al. } \\
(2017)\end{array}$ \\
\hline 25 & $\begin{array}{l}\text { Chinese } \\
\text { population }\end{array}$ & Case control study & $\begin{array}{l}\text { TCF7L2 variant rs7903146 increases susceptibility to } \\
\text { DN (diabetic neuropathy) in Chinese population. }\end{array}$ & $\begin{array}{l}\text { Zhuang et al. } \\
\text { (2018) }\end{array}$ \\
\hline 26 & $\begin{array}{l}\text { Nanjing } \\
\text { population of } \\
\text { china }\end{array}$ & Meta analysis & $\begin{array}{l}\text { TCF7L2 variant rs } 12255372 \text { strongly associated with } \\
\text { Type } 2 \text { diabetes in the Chinese population }\end{array}$ & $\begin{array}{l}\text { Yan li et al. } \\
(2018)\end{array}$ \\
\hline 27 & $\begin{array}{l}\text { Pakistani } \\
\text { population }\end{array}$ & Case control study & $\begin{array}{l}\text { TCF7L2 variant rs } 12255372 \text { had strong association } \\
\text { in regulating fasting plasma glucose }\end{array}$ & $\begin{array}{l}\text { Shahzadi et al. } \\
(2019)\end{array}$ \\
\hline 28 & $\begin{array}{l}\text { Iranians } \\
\text { population }\end{array}$ & $\begin{array}{l}\text { GWAS (genome wide } \\
\text { association study) }\end{array}$ & $\begin{array}{l}\text { TCF7L2 variants rs7903146, rs } 12255372 \\
\text { and rs } 11255372 \text { is found to have promising role } \\
\text { in the incidence of type } 2 \text { diabetes. }\end{array}$ & $\begin{array}{l}\text { Kalantari et al. } \\
(2019)\end{array}$ \\
\hline 29 & $\begin{array}{l}\text { Puerto Ricans } \\
\text { population }\end{array}$ & Case control study & $\begin{array}{l}\text { TCF7L2 -rs7903146 showes significant interaction } \\
\text { with BMI,weight and wait circumference hence } \\
\text { leading to Type } 2 \text { diabetes. }\end{array}$ & $\begin{array}{l}\text { Mercedes et al. } \\
(2020)\end{array}$ \\
\hline
\end{tabular}

\section{PUZZLED MECHANISM OF TCF7L2 ALLELES CAUSING TYPE 2 DIABETES}

The Wnt signaling pathways is greatly important in regulating carcinogenesis and embryonic development (stem cell differentiation, amplification and migration) also involved in the development of the body parts [52, 53]. Wnt signaling pathway (the canonical pathway or beta-catenin/ TCF7L2-dependent pathway) is expressed in liver, pancreas, brain and adipose tissues [54]. In pancreas it helps in the development of pancreas, islet function, insulin production and secretion. In beta cells of pancreas canonical wnt signaling is modulated by two hormones namely glucoincretin hormone glucagon-like peptide- 1 and the chemokine stromal cellderived factor-1, furthermore glucagon-like peptide-1and its agonist exendin-4 restore the pancreatic beta cells mass by switching on Wnt signaling which then start proliferation to restore mass of beta cell [55]. Genome-wide association studies (GWAS) have identified several risk variants in TCF7L2 that is found culprit in type 2 diabetes. Interestingly most of these risk variants encode proteins that are involved in islet growth and functioning. Seven of them are part of genes that regulate Wnt signaling. Thus canonical Wnt signaling and beta-cell function is greatly influenced by TCF7L2 mutation. Polymorphism in TCF7L2 leads to loss in function of pancreas; impair insulin secretion, perturbations in the Wnt signaling pathway that leads to type 2 diabetes $[56,57]$.

\section{CONCLUSION}

Candidate gene association studies (CGAS) and genome wide association studies (GWAS) identified multiple genes associated with diabetes type 2, transcription factor 7-like 2 (TCF7L2) is gang head of type 2 diabetes susceptible genes [58]. Risk variants leads to over-expression of TCF7L2 gene in beta cells of pancreas but the mechanism is not fully understood and it is a question which is still need to be answered by geneticists, resulting in reducing secretion of insulin from beta cells and hence increasing blood sugar level $[59,60]$. Comprehensive knowledge about TCF7L2 have significant role in controlling diabetes, separating and identifying the prospective diabetes individuals with high risk diabetes associated loci in a population so that preventive measures can be initiated [61, 62].

\section{ADDITIONAL INFORMATION}

Funding. None.

Conflict of interest. None.

Author Contribution. Asif Jan contributed in literature search, finalizing topic, write-up, giving final shape to this review paper and submission of paper. Humerah Jan and Zaki Ullah helped in writing the manuscript.

Acknowledgement. This review paper was supported by Dr Hamayun. We are thankful for his moderation throughout the paper. We are also thankful to Dr Sidra who helped us for writing manuscript. 


\section{СПИСОК ЛИТЕРАТУРЫ | REFERENCES}

1. Adeghate E, Schattner P, Dunn E. An Update on the Etiology and Epidemiology of Diabetes Mellitus. Ann N Y Acad Sci. 2006;1084(1):1-29. doi: https://doi.org/10.1196/annals.1372.029

2. Mayor S. Diabetes affects nearly $6 \%$ of the world's adults. BMJ. 2006; 28(1):21-24. https://doi.org/10.1136/bmj.39055.608507.DB

3. Gujral UP, Pradeepa R, Weber MB, et al. Type 2 diabetes in South Asians: similarities and differences with white Caucasian and other populations. Ann N Y Acad Sci. 2013;1281 (1):51. doi: https://doi.org/10.1371/journal.pone.0184967

4. Sherin A. National diabetes action plan of Pakistan: need and challenges. Khyber Medical University Journal. 2015;7(1):1-2.

5. Rowley WR, Bezold C, Arikan Y, Byrne E, Krohe S. Diabetes 2030: insights from yesterday, today, and future trends. Population health management. 2017;20(1):6-12. doi: https://doi.org/10.1089/pop.2015.0181

6. Cade WT. Diabetes-related microvascular and macrovascular diseases in the physical therapy setting. Physical therapy. 2008;88(11):1322-1335. doi: https://doi.org/10.2522/2Fptj.20080008

7. American Diabetes Association. Diagnosis and classification of diabetes mellitus. Diabetes care. 2009; 1;32(Supplement 1):S62-S67. doi: https://doi.org/10.2337/2Fdc09-S062

8. Boutayeb A. The double burden of communicable and non-communicable diseases in developing countries. Trans R Soc Trop Med Hyg. 2006;100(3):191-199. doi: https://doi.org/10.1016/j.trstmh.2005.07.021

9. Basit A, Fawwad A, Qureshi H, Shera AS. Prevalence of diabetes, pre-diabetes and associated risk factors: second National Diabetes Survey of Pakistan (NDSP), 2016-2017. BMJ open. 2018;8(8):e020961. doi: http://doi.org/10.1136/bmjopen-2017-020961

10. Elbein SC. Perspective: the search for genes for type 2 diabetes in the post-genome era. Endocrinology. 2002;143(6):2012-8. doi: https://doi.org/10.1210/endo.143.6.8831

11. Bell II. The double helix in clinical practice. Nature. 2003;421(6921):414-6. doi: https://doi.org/10.1038/nature01402

12. Holtzman NA, Marteau TM. Will genetics revolutionize medicine? N Eng J Med. $2000 ; 343(2): 141-4$. doi: https://doi.org/10.1056/nejm200007133430213

13. Phillips DIW, Tuomilehto J. Can twin studies assess the genetic component in Type 2 (non-insulin-dependent) diabetes mellitus? Diabetologia. 1993;36(5):471-472. doi: https://doi.org/10.1007/BF00402287

14. Cammidge PJ. Diabetes mellitus and heredity. British medical journal. 1928;2(3538):738. doi: https://doi.org/10.1136/2Fbmj.2.3538.738

15. Kaprio J, Tuomilehto J, Koskenvuo M, et al. Can twin studies assess the genetic component in type-2 (non-insulindependent) diabetes-mellitus-reply. Diabetologia. 1993;36:472. doi: https://doi.org/10.1007/BF02221682

16. Mueckler M. Family of glucose-transporter genes: implications for glucose homeostasis and diabetes. Diabetes. 1990;39(1):6-11. doi: https://doi.org/10.2337/diacare.39.1.6

17. Gloyn AL, Weedon MN, Owen KR, et al. Large-Scale Association Studies of Variants in Genes Encoding the Pancreatic -Cell KATP Channel Subunits Kir6.2 (KCNJ11) and SUR1 (ABCC8) Confirm That the KCNJ11 E23K Variant Is Associated With Type 2 Diabetes. Diabetes. 2003;52(2):568-572. doi: https://doi.org/10.2337/diabetes.52.2.568

18. Altshuler D, Hirschhorn JN, Klannemark M, et al. The common PPARY Pro12Ala polymorphism is associated with decreased risk of type 2 diabetes. Nat Gen. 2000;26(1):76-80. doi: https://doi.org/10.1038/79216

19. Barroso I, Gurnell M, Crowley VE, et al. Dominant negative mutations in human PPARy associated with severe insulin resistance, diabetes mellitus and hypertension. Nature. 1999:402(6764):880-3. doi: https://doi.org/10.1038/47254

20. Gloyn AL, Pearson ER, Antcliff JF, et al. Activating mutations in the gene encoding the ATP-sensitive potassium-channel subunit Kir6. 2 and permanent neonatal diabetes. N Eng J Med. 2004;350(18):1838-49.doi

21. Kingsmore SF, Lindquist IE, Mudge J, et al. Genome-wide association studies: progress and potential for drug discovery and development. Nat Rev Drug Discov. 2008;7(3):221-230. doi: https://doi.org/10.1038/nrd2519

22. Frayling TM, Genome-wide association studies provide new insights into type 2 diabetes aetiology. Nat Rev Gen. 2007; 8(9):657-662.

\section{doi: https://doi.org/10.1038/nrg2178}

23. Kato N. Insights into the genetic basis of type 2 diabetes. J Diabetes Investig. 2013;4(3):233-44. doi: https://doi.org/10.1111/2Fjdi.12067

24. Saxena R, Voight BF, Lyssenko V, et al. Genome-Wide Association Analysis Identifies Loci for Type 2 Diabetes and Triglyceride Levels. Science (80- ). 2007;316(5829):1331-1336. doi: https://doi.org/10.1126/science.1142358

25. Grant SFA, Thorleifsson G, Reynisdottir I, et al. Variant of transcription factor 7-like 2 (TCF7L2) gene confers risk of type 2 diabetes. Nat Genet. 2006;38(3):320-323 doi: https://doi.org/10.1038/ng1732

26. Zeggini E, McCarthy MI. TCF7L2: the biggest story in diabetes genetics since HLA? Diabetologia. 2006;50(1):1-4. doi: https://doi.org/10.1007/s00125-006-0507-x

27. Chandak GR, Janipalli CS, Bhaskar S, et al. Common variants in the TCF7L2 gene are strongly associated with type 2 diabetes mellitus in the Indian population. Diabetologia. 2007;50(1):63-67. doi: https://doi.org/10.1007/s00125-006-0502-2

28. Hayashi T, Iwamoto Y, Kaku K, et al. Replication study for the association of TCF7L2 with susceptibility to type 2 diabetes in a Japanese population. Diabetologia. 2007;50(5):980-984. doi: https://doi.org/10.1007/s00125-007-0618-z

29. Horikawa Y, Miyake K, Yasuda K, et al. Replication of GenomeWide Association Studies of Type 2 Diabetes Susceptibility in Japan. J Clin Endocrinol Metab. 2008;93(8):3136-3141. doi: https://doi.org/10.1210/jc.2008-0452

30. Lehman DM, Hunt KJ, Leach RJ, et al. Haplotypes of Transcription Factor 7-Like 2 (TCF7L2) Gene and Its Upstream Region Are Associated With Type 2 Diabetes and Age of Onset in Mexican Americans. Diabetes. 2007;56(2):389-393. doi: https://doi.org/10.2337/db06-0860

31. Dou $H, M a E$, Yin $L$, et al. The association between gene polymorphism of TCF7L2 and type 2 diabetes in Chinese Han population: a meta-analysis. PloS one. 2013;8(3):e59495. doi: https://doi.org/10.1371/journal.pone.0059495

32. Helgason A, Pálsson S, Thorleifsson G,et al. Refining the impact of TCF7L2 gene variants on type 2 diabetes and adaptive evolution. Nat Gen. 2007;39(2):218-225. doi: https://doi.org/10.1038/ng1960

33. Florez JC, Jablonski KA, Bayley N, et al. TCF7L2 Polymorphisms and Progression to Diabetes in the Diabetes Prevention Program. N Engl J Med. 2006;355(3):241-250. doi: https://doi.org/10.1056/NEJMoa062418

34. Nobrega MA. TCF7L2 and Glucose Metabolism: Time to Look Beyond the Pancreas. Diabetes. 2013;62(3):706-708. doi: https://doi.org/10.2337/db12-1418

35. Loos RJ, Franks PW, Francis RW,et al. TCF7L2 polymorphisms modulate proinsulin levels and $\beta$-cell function in a British Europid population. Diabetes. 2007;56(7):1943-1947. doi: https://doi.org/10.2337/db07-0055

36. Sladek R, Rocheleau G, Rung J, et al. A genome-wide association study identifies novel risk loci for type 2 diabetes. Nature. 2007;445(7130):881-885. doi: https://doi.org/10.1038/nature05616

37. Salonen JT, Uimari P, Aalto J-M, et al. Type 2 Diabetes Whole-Genome Association Study in Four Populations: The DiaGen Consortium. Am J Hum Genet. 2007;81 (2):338-345. doi: https://doi.org/10.1086/520599

38. Savic $D$, Ye H, Aneas I, et al. Alterations in TCF7L2 expression define its role as a key regulator of glucose metabolism. Genome Res. 2011;21(9):1417-1425. doi: https://doi.org/10.1101/gr.123745.111

39. Wei L, Xiao Y, Li L, et al. The susceptibility genes in diabetic nephropathy. Kidney Dis (Basel). 2018:4(4):226-37. doi: https://doi.org/10.1159/000492633

40. Prokunina-Olsson L, Welch C, Hansson O, et al. Tissue-specific alternative splicing of TCF7L2. Hum Mol Genet. 2009;18(20):3795-3804. doi: https://doi.org/10.1093/hmg/ddp321

41. Castrop J, van Norren K, Clevers H. A gene family of HMG-box transcription factors with homology to TCF-1. Nucleic Acids Res. 1992;20(3):611. doi: https://doi.org/10.1093/nar/20.3.611

42. Jin T, Liu L. Minireview: The Wnt Signaling Pathway Effector TCF7L2 and Type 2 Diabetes Mellitus. Mol Endocrinol. 2008;22(11):2383-2392. doi: https://doi.org/10.1210/me.2008-0135

43. Migliorini A, Lickert $\mathrm{H}$. Beyond association: A functional role for Tcf7l2 in $\beta$-cell development. Mol Metabol. 2015;4(5):365. doi: https://doi.org/10.1016/j.molmet.2015.03.002 
44. Nobrega MA. TCF7L2 and glucose metabolism: time to look beyond the pancreas. Diabetes. 2013;62(3):706-708. doi: https://doi.org/10.2337/db12-1418

45. Weedon MN. The importance of TCF7L2. Diabet Med. 2007;24(10):1062-1066. doi: https://doi.org/10.1111/j.1464-5491.2007.02258.x

46. Tam V, Patel N, Turcotte $M$, et al. Benefits and limitations of genome-wide association studies. Nat Rev Gen. 2019;20(8):467-484 doi: https://doi.org/10.1038/s41576-019-0127-1

47. Hirschhorn JN, Daly MJ. Genome-wide association studies for common diseases and complex traits. Nat Rev Gen. 2005;6(2):95-108 doi: https://doi.org/10.1038/nrg1521

48. Cauchi S, Meyre D, Dina C, et al. Transcription factor TCF7L2 genetic study in the French population: expression in human $\beta$-cells and adipose tissue and strong association with type 2 diabetes. Diabetes. 2006;55(10):2903-2908. doi: https://doi.org/10.2337/db06-0474

49. Zeggini $\mathrm{E}$, Weedon MN, Lindgren CM, et al. The Wellcome Trust Case Control Consortium. Replication of genome-wide association signals in UK samples reveals risk loci for Type 2 diabetes. Science. 2007;316:1336-1341. doi: https://doi.org/10.1126/science.1142364

50. Luo $Y$, Wang $H$, Han $X$, et al. Meta-analysis of the association between SNPs in TCF7L2 and type 2 diabetes in East Asian population. Diabet Res Clin Prac. 2009;85(2):139-146. doi: https://doi.org/10.1016/j.diabres.2009.04.024

51. Scott $L$, Mohlke KL, Bonnycastle LL, et al. A genome-wide association study of type 2 diabetes in Finns detects multiple susceptibility variants. Science. 2007;316(5829):1341-1345. doi: https://doi.org/10.1126/science.1142382

52. Jin T. Current understanding on role of the Wnt signaling pathway effector TCF7L2 in glucose homeostasis. Endocrin Rev. 2016;37(3):254-277. doi: https://doi.org/10.1210/er.2015-1146
53. Shao W, Wang D, Chiang YT, et al. The Wnt signaling pathway effector TCF7L2 controls gut and brain proglucagon gene expression and glucose homeostasis. Diabetes. 2013;62(3):789-800. doi: https://dx.doi.org/10.2337/2Fdb12-0365

54. Ip W, Chiang YT, Jin T. The involvement of the wnt signaling pathway and TCF7L2 in diabetes mellitus: The current understanding, dispute, and perspective. Cell \& Bioscience. 2012;2(1):1-2. doi: https://dx.doi.org/10.1186/2F2045-3701-2-28

55. Liu Z, Habener JF. Wnt signaling in pancreatic islets. The islets of langerhans. 2010:391-419. doi: https://doi.org/10.1007/978-90-481-3271-3_17

56. Ng LF, Kaur P, Bunnag N, et al. WNT signaling in disease. Cells. 2019;8(8):826. doi: https://doi.org/10.3390/cells8080826

57. Mahajan A, Go MJ, Zhang W, et al. Genome-wide trans-ancestry meta-analysis provides insight into the genetic architecture of type 2 diabetes susceptibility. Nat Gen. 2014; 46(3):234-244. doi: https://doi.org/10.1038/ng.2897

58. Hattersley AT. Prime suspect: the TCF7L2 gene and type 2 diabetes risk. J Clin Invest. 2007;117(8):2077-2079. doi: https://doi.org/10.1172/JCl33077

59. Loder MK, Xavier GD, McDonald A, Rutter GA. TCF7L2 controls insulin gene expression and insulin secretion in mature pancreatic $\beta$-cells. Biochem Soc Trans. 2008;36(Pt 3):357-359. doi: https://doi.org/10.1042/bst0360357

60. da Silva Xavier G, Loder MK, MCDonald A, et al. TCF7L2 regulates late events in insulin secretion from pancreatic islet $\beta$-cells. Diabetes. 2009;58(4):894-905. doi: https://doi.org/10.2337/db08-1187

61. Sanghera DK, Blackett PR. Type 2 diabetes genetics: beyond GWAS. J Diabet Metab. 2012;3(198):6948 doi: https://doi.org/10.1038/nrendo.2014.11

62. Hivert MF, Vassy JL, Meigs JB. Susceptibility to type 2 diabetes mellitusfrom genes to prevention. Nat Rev Endocrinol. 2014;10(4):198-205. doi: https://doi.org/10.4172/2F2155-6156.1000198

\section{AUTHORS INFO}

Asif Jan, Department of Pharmacy, University of Peshawar, Khyber Pakhtunkhwa (KP), Pakistan. ORCID: https://orcid.org/0000-0003-3880-5579; e-mail: Asif.research1@gmail.com

Humerah Jan; ORCID: https://orcid.org/0000-0002-1792-2912; e-mail: Humerahjan@gmail.com Zaki Ullah; ORCID: https://orcid.org/0000-0001-7932-9498; e-mail: zakiullah@uop.edu.pk

\section{ЦИТИРОВАТЬ:}

Jan A., Jan H., Ullah Z. Фактор транскрипции 7 (TCF7L2): фактор риска развития сахарного диабета 2 типа // Сахарный диабеm. - 2021. — T. 24. — №4. — C. 371-376. doi: https://doi.org/10.14341/DM12313

TO CITE THIS ARTICLE:

Jan A, Jan H, Ullah Z. Transcription factor 7-like 2 (TCF7L2): a culprit gene in Type 2 Diabetes Mellitus. Diabetes Mellitus. 2021;24(4):371-376. doi: https://doi.org/10.14341/DM12313 